\title{
THE HIGH-TEMPERATURE STRENGTH AND PLASTIC PROPERTIES OF SELECTED LOW-ALLOYED Cr-MO STEELS
}

\author{
Petr KAWULOK, Petr KAJZAR, Ivo SCHINDLER, Rostislav KAWULOK, Tomáš KUBINA, \\ Horymír NAVRÁTIL
}

\author{
VSB - Technical University of Ostrava, Faculty of Materials Science and Technology, \\ Ostrava, Czech Republic, EU, \\ petr.kawulok@vsb.cz,petr.kajzar.st@vsb.cz,ivo.schindler@vsb.cz, rostislav.kawulok@vsb.cz, \\ tomas.kubina@vsb.cz, horymir.navratil@vsb.cz
}

https://doi.org/10.37904/metal.2019.811

\begin{abstract}
With using of the simulator HDS-20, the strength and plastic properties of two selected low-alloyed Cr-Mo steels, which were differing by carbon and manganese content, were experimentally investigated. By a special test consisting of loading of tested specimen by the small constant tensile force of $80 \mathrm{~N}$ in the whole course of his heating, the nil-strength temperature of the investigated steels was determined. The steel with the higher carbon content showed about of $42{ }^{\circ} \mathrm{C}$ lower nil-strength temperature. By uniaxial tensile tests to rupture which were performed in the range of deformation temperatures of $800-1410^{\circ} \mathrm{C}$ at the constant tensile rate of $20 \mathrm{~mm} \cdot \mathrm{s}^{-1}$ and $1000 \mathrm{~mm} \cdot \mathrm{s}^{-1}$, the strength and plastic properties of the investigated steels were examined. The different carbon content did not significantly influence the strength properties of the investigated steels in the examined range of deformation temperatures. In the case of the hot ductility, similar results were obtained, but the steel with the higher carbon content showed about of $35^{\circ} \mathrm{C}$ lower nil-ductility temperature. The difference between the nil-strength temperature and nil-ductility temperature was $39^{\circ} \mathrm{C}$ and $32{ }^{\circ} \mathrm{C}$ in the case of the steel with the carbon content of 0.31 wt. $\%$ and 0.43 wt. $\%$, respectively.
\end{abstract}

Keywords: Cr-Mo steels, tensile tests, nil-strength temperature, nil-ductility temperature

\section{INTRODUCTION}

The main aim of the presented work is the study of the high temperature strength and plastic properties of the chosen low alloy Cr-Mo steels with various carbon and manganese contents. Strength and plastic properties, or the formability of materials at high temperatures is possible to research with the application of uniaxial tensile tests to rupture. The formability, or plastic properties of the tested material in this case are evaluated from the overall elongation of the tested rod into rupture or from their contraction [1-7].

Temperature is an important parameter not only for production processes, casting and hot forming, but also for example for welding of steels. Due to the optimization of the current processes of production steels is important to know the temperatures of phase transformations, or temperatures, during which steel loses plasticity or strength [8-11]. The nil-strength temperature $N S T\left({ }^{\circ} \mathrm{C}\right)$ corresponds to the temperature of burning of material during his heating and can be determined in the research of brittleness at high temperatures, for example during welding, casting or during determining of upper forming temperatures. In the literature, pertaining to mostly the processes of welding and forming of materials, nil-strength temperature is defined as the temperature, during which metals lose all their strength due to the melting of grain boundaries, which means that during this temperature, materials can't withstand any load [9-11]. The nil-strength temperature is therefore lower than liquidus temperature $-T L\left({ }^{\circ} \mathrm{C}\right)$ - see Figure 1. Whereas the nil-ductility temperature NDT $\left({ }^{\circ} \mathrm{C}\right)$ corresponds to temperature, during which the ductility of material is equal to zero (achieving of $100 \%$ brittleness). The value of NDT is determined with using of tensile tests with direct heating to the deformation temperature - see Figure 1. It is important to know the nil-strength temperature of steels, especially to eliminate cracking during high temperatures (for example during welding or casting), because this temperature together 
with the ductility recovery temperature $D R T\left({ }^{\circ} \mathrm{C}\right)$ delimits the brittleness temperature range - BTR (see Figure 1). In this range are the metals during their solidification sensitive to segregational cracking due to local loss of ductility of grain boundaries $[1,9,12]$. The ductility recovery temperature $D R T\left({ }^{\circ} \mathrm{C}\right)$ is determined by tensile tests after a uniform preheating to tested rods a temperature lower than $N S T$ with a subsequent cooling to the chosen deformation temperature. The DRT should be correspond to approximately $5 \%$ of the material's ductility - see Figure 1. The DRT and $N D T$ delimit the nil-ductility range - NDR [9].

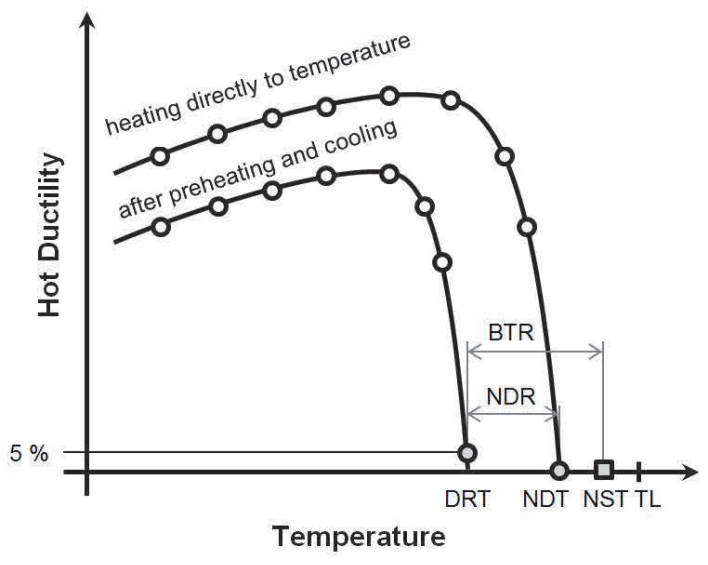

Figure 1 Diagram of temperatures characterizing brittleness temperature range (based on [9])

\section{EXPERIMENT DESCRIPTION}

For the purposes of the presented works, two low alloy Cr-Mo steels were selected, which were supplied as seamless tubes (with an initial fine grain structure), and were differed mainly in their carbon and manganese contents - see Table 1.

Table 1 Chemical composition of investigated steels in wt $\%$

\begin{tabular}{|c|c|c|c|c|c|c|c|c|c|c|}
\hline Steel & $\mathbf{C}$ & $\mathbf{M n}$ & $\mathbf{S i}$ & $\mathbf{P}$ & $\mathbf{S}$ & $\mathbf{N i}$ & $\mathbf{C r}$ & $\mathbf{M o}$ & $\mathbf{V}$ & $\mathbf{N}$ \\
\hline A & 0.31 & 0.52 & 0.292 & 0.016 & 0.008 & 0.08 & 1.04 & 0.221 & 0.009 & 0.0088 \\
\hline B & 0.43 & 0.80 & 0.270 & 0.012 & 0.011 & 0.02 & 1.01 & 0.193 & 0.004 & 0.0044 \\
\hline
\end{tabular}

These experimental works were divided into three stages. In the first stage, the nil-strength temperature of the investigated steels was determined. In the second stage, the plastic properties of both steels in a wide range of deformation temperatures were investigated with using of the uniaxial tensile test. In the last stage, the influence of deformation temperature on the mean diameter of initial austenitic grain was investigated. All stages were realized with using of the simulator HDS-20.

The nil-strength temperature was determined only in the case of steel $A$, because for steel $B$ was this temperature determined already earlier [13]. For purposes of determining of the nil-strength temperature the cylindrical specimens with diameter of $6 \mathrm{~mm}$ and length of $81 \mathrm{~mm}$ were prepared from steel $A$. These specimens were then heated up in two stages by electrical resistant heating and during the whole test there was a small constant tensile force of $80 \mathrm{~N}$ applied to the specimens. The specimens were heated up with the rate $20{ }^{\circ} \mathrm{C} \cdot \mathrm{s}^{-1}$ to the temperature $1,200{ }^{\circ} \mathrm{C}$ and then they were slowly heated at the rate $2{ }^{\circ} \mathrm{C} \cdot \mathrm{s}^{-1}$ from this temperature to the moment of their rupture. In order to eliminate possible inhomogeneities in the investigated steel, and in order make a statistical evaluation, this test was performed 3 times in the same conditions.

For the uniaxial tensile tests the cylindrical specimens with diameter of $10 \mathrm{~mm}$ and length of $116.5 \mathrm{~mm}$, which were threaded at the ends, were prepared from booth of investigated steel. These specimens were then attached into stainless steel jaws with a partial contact area and were electrical resistance heated with the rate $10^{\circ} \mathrm{C} \cdot \mathrm{s}^{-1}$ directly to the deformation temperatures, which was selected in the range of $800{ }^{\circ} \mathrm{C}-1,410{ }^{\circ} \mathrm{C}$. After uniform 5 minutes dwell time at the deformation temperature were these specimens deformed by tensile until rupture at the constant tensile rate of $20 \mathrm{~mm} \cdot \mathrm{s}^{-1}$ or $1,000 \mathrm{~mm} \cdot \mathrm{s}^{-1}$, which corresponds to the mean strain rate at the beginning of the test ca. 1.6, or $75 \mathrm{~s}^{-1}$. In the case of steel $\mathrm{B}$ the earlier measured data for tensile rate $20 \mathrm{~mm} \cdot \mathrm{s}^{-1}$ were used [13]. 
For the purposes of determining the influence of deformation temperature on the mean diameter of the initial austenitic grain after heating of the investigated steels to the selected deformation temperatures and subsequent 5 minutes dwell time, the specimens (with diameter $10 \mathrm{~mm}$ and length $116.5 \mathrm{~mm}$ ) were quenched in water. For the steel A were selected temperatures $900^{\circ} \mathrm{C} ; 1,100{ }^{\circ} \mathrm{C} ; 1,300^{\circ} \mathrm{C}$ and $1,400{ }^{\circ} \mathrm{C}$. For steel $\mathrm{B}$ were selected temperatures $950^{\circ} \mathrm{C} ; 1,100{ }^{\circ} \mathrm{C} ; 1,250{ }^{\circ} \mathrm{C}$ and $1,350{ }^{\circ} \mathrm{C}$. Subsequently, these samples were subjected to metallographic analyses aimed at etching the boundaries of the original austenitic grain. The cross section in the centre of the length of the specimens was investigated.

\section{PROCESSING OF MEASURED DATA AND DISCUSSION OF RESULTS}

The experimentally determined nil-strength temperature corresponds to the highest value of the registered temperature at the moment of rupture of the tested specimen (due to the combination of melting of grain boundaries and the action of a very small tensile force). This phenomenon is easily identifiable, because it is accompanied by a steep declination of measured temperature, or by her steep increase, which is caused by the loosening of the thermocouple wires (see Figure 2 and Figure 3). From the measured nil-strength temperatures of the investigated steels subsequently their mean value $N S T_{\text {(mean) }}\left({ }^{\circ} \mathrm{C}\right)$ and their standard deviation was determined. For steel A was $N S T_{\text {(mean) }}=1,444{ }^{\circ} \mathrm{C}$ (standard deviation $5.9{ }^{\circ} \mathrm{C}$ ) and for steel B was $N S T_{\text {(mean) }}=1,402{ }^{\circ} \mathrm{C}$ (standard deviation $2^{\circ} \mathrm{C}$ ). The higher carbon content in the investigated steel $\mathrm{B}$, in comparison to steel $\mathrm{A}$, lead to decrease in temperature $N S T_{\text {(mean) }}$ by $42^{\circ} \mathrm{C}$.

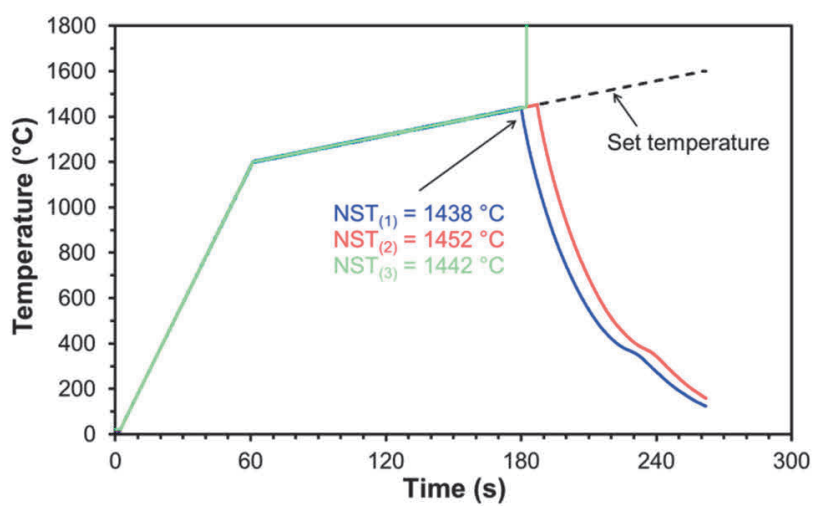

Figure 2 The measured nil-strength temperature of steel $A$

From the data registered during the uniaxial tensile tests, there were tensile diagrams prepared, which documents the relationships between the measured force and the total elongation - see example in Figure 4. From these diagrams it was possible to determine the maximum force values $F_{\max }(\mathrm{kN})$ and total elongation to the rupture $\Delta L(\mathrm{~mm})$. These values were then used for the calculation of the contractual hot ultimate tensile strength $U T S_{H}(\mathrm{MPa})$ and hot ductility $A_{H}(\%)$ of all ruptured specimens:

$U T S_{H}=\frac{F_{\max .} \cdot 1000}{S_{0}}$

$A_{H}=\frac{\Delta L}{L_{0}} \cdot 100$

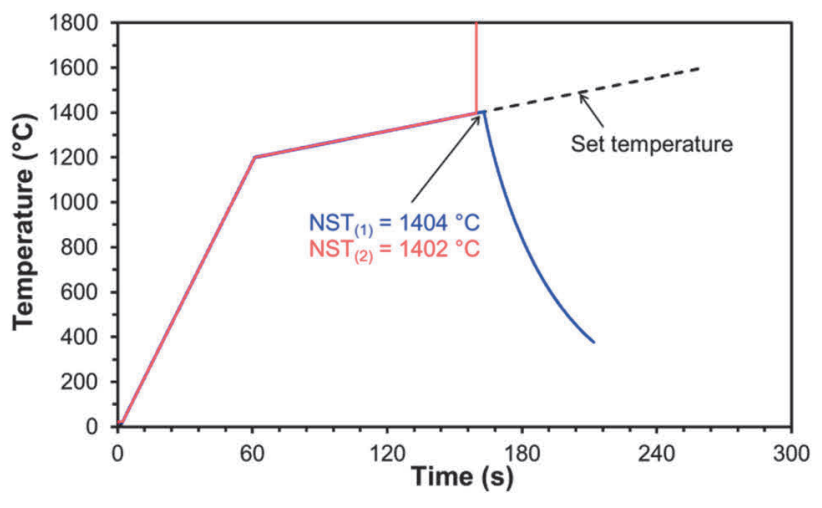

Figure 3 The measured nil-strength temperature of steel B [13]

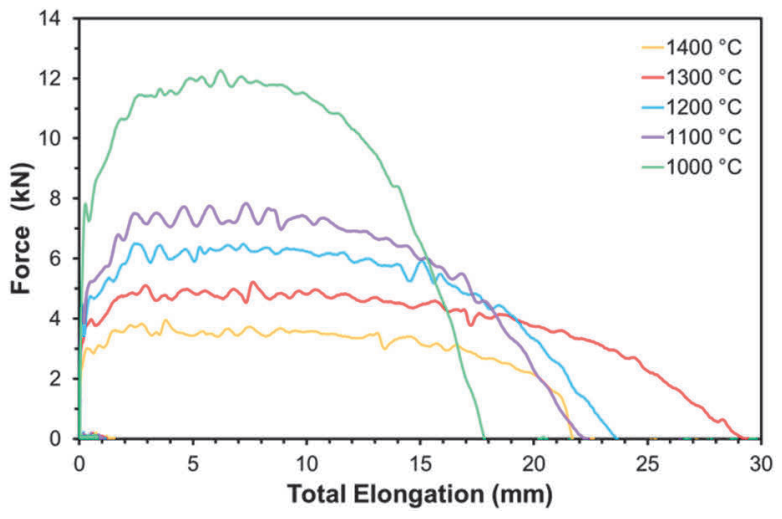

Figure 4 Selected tensile diagrams of steel A tensile rate $1,000 \mathrm{~mm} \cdot \mathrm{s}^{-1}$ 
where $S_{0}(\mathrm{~mm})$ is the initial cross-sectional area of the tested specimens and $L_{0}(\mathrm{~mm})$ is the measured length, which was (in the case of the used jaws from stainless steel and the dimensions of the tested specimens) equal to $20 \mathrm{~mm}$. The relationship between the contractual hot ultimate tensile strength and hot ductility at the deformation temperature in the case of both investigated steels can be seen in Figure $\mathbf{5}$ and Figure $\mathbf{6}$.

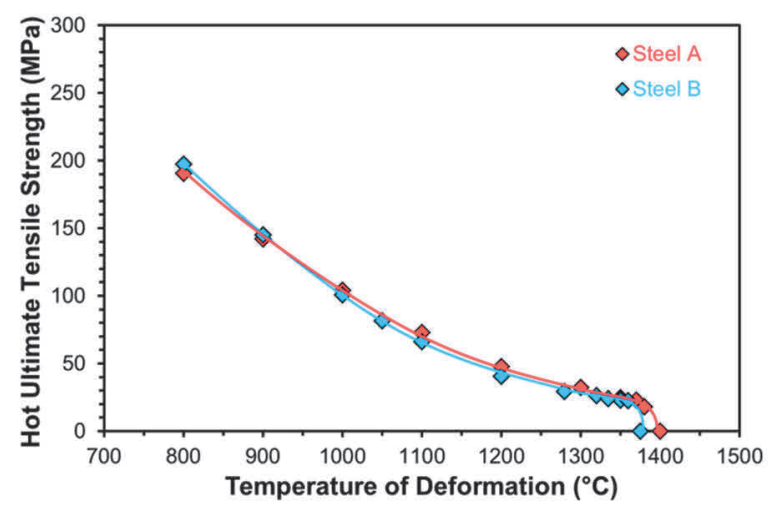

a) tensile rate $20 \mathrm{~mm} \cdot \mathrm{s}^{-1}$

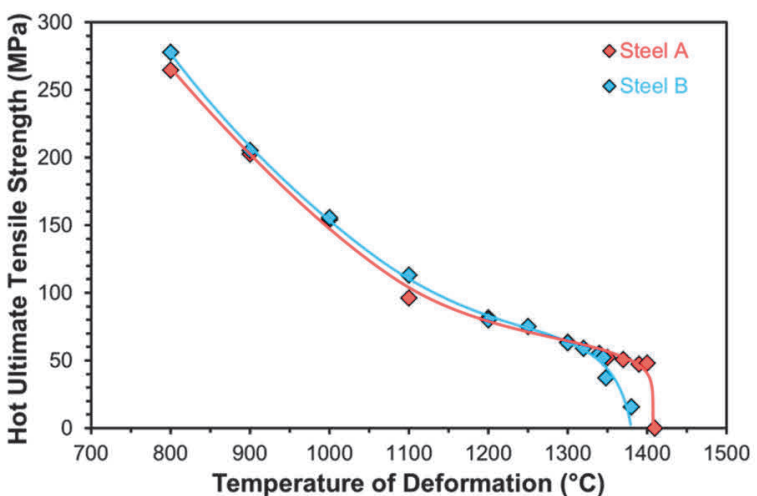

b) tensile rate $1,000 \mathrm{~mm} \cdot \mathrm{s}^{-1}$

Figure $\mathbf{5}$ The contractual hot ultimate tensile strength of the investigated steels

With increasing of deformation temperature, the deformation resistance and therefore the contractual hot ultimate tensile strength decreased (see Figure 5). The applied higher tensile rate (a higher mean strain rate) caused an increase contractual hot ultimate tensile strength. With the exception of cases influenced by practically zero formability, there wasn't registered any significant impact of the higher content of carbon and manganese in steel $\mathrm{B}$, with comparison to steel $\mathrm{A}$, on the amount of contractual hot ultimate tensile strength. Only in the case of uniaxial tensile tests performed at tensile rate of $1,000 \mathrm{~mm} \cdot \mathrm{s}^{-1}$ it can be observe a slight increase of contractual hot ultimate tensile strength of steel B.

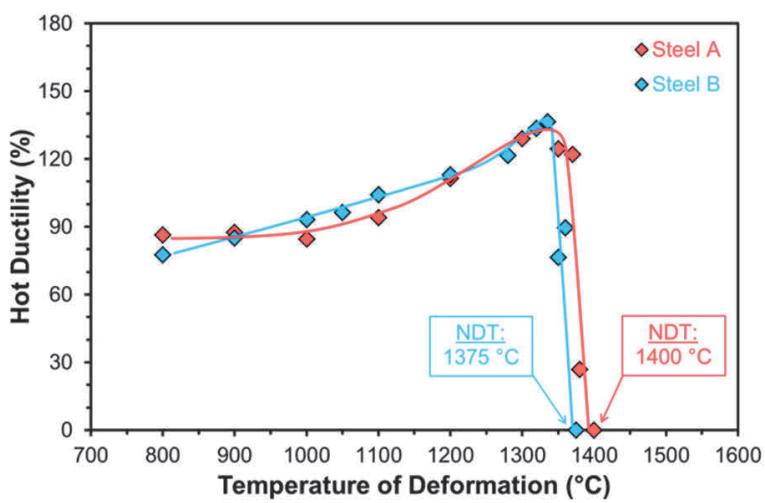

a) tensile rate $20 \mathrm{~mm} \cdot \mathrm{s}^{-1}$

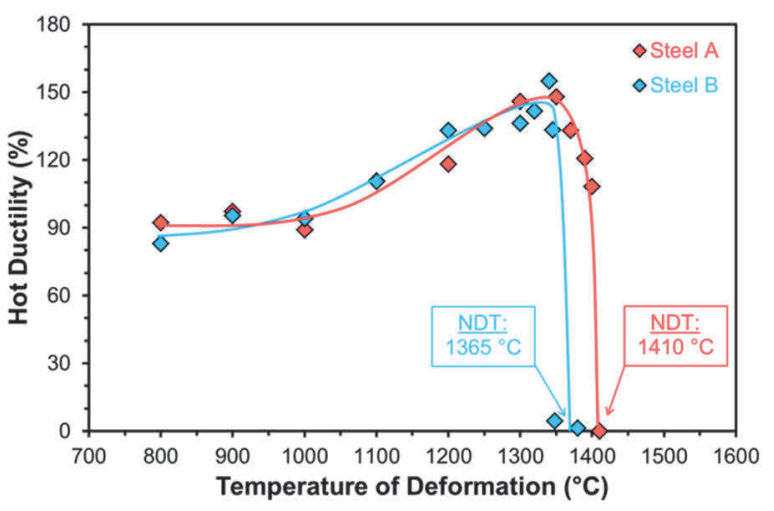

b) tensile rate $1,000 \mathrm{~mm} \cdot \mathrm{s}^{-1}$

Figure 6 The hot ductility of the investigated steels

With considering the scatter of the measured data, the hot ductility of both investigated steels in the range of the deformation temperatures $800-1,340{ }^{\circ} \mathrm{C}$ was practically the same (see Figure 6 ). In the literature, it is possible to find papers [14,15], in which the plastic properties of Cr-Mo steels are investigated in the range of the temperatures $700-1,100{ }^{\circ} \mathrm{C}$. In the papers [14,15], the plastic properties of their investigated steels decreased uniformly along with the deformation temperature until the temperature $800{ }^{\circ} \mathrm{C}$, as in the case of our investigated steels. Unfortunately, it wasn't find results of the plastic properties of Cr-Mo steels for temperatures higher than $1,300{ }^{\circ} \mathrm{C}$. On the basis of the results of the uniaxial tensile tests presented in this 
work (see Figure 6) it was found, that only a small difference in carbon and manganese content in the investigated steel had an effect on their plastic properties at very high temperatures. At deformation temperatures above $1,340{ }^{\circ} \mathrm{C}$, there was a rapid decrease of hot ductility of both investigated steels due to overheating and burning. The steel $B$ (with higher carbon and manganese content) showed, that in comparison with the steel A (with a lower carbon and manganese content), earlier decrease of hot ductility (see Figure 6). On the basis of the results of the uniaxial tensile tests (performed at both tensile rates) the values of NDT were determined and then the mean value of $N D T_{\text {(mean) }}$ of both investigated steels were determined - see Table 2. Steel A (with a lower carbon and manganese content) therefore showed a $35^{\circ} \mathrm{C}$ higher nil-ductility temperature than steel B (with a higher carbon and manganese content). The applied differed strain rates didn't have a significant effect on the nil-ductility temperature of the investigated steels. The difference between the nilstrength temperature and nil-ductility temperature was in the case of steel $\mathrm{A} 39^{\circ} \mathrm{C}$, and $32{ }^{\circ} \mathrm{C}$ in in the case of steel B.

Table 2 The nil-ductility temperature of the investigated steels

\begin{tabular}{|c|c|c|c|}
\hline Steel & $\mathbf{N D T}-\mathbf{2 0} \mathbf{~} \mathbf{m} \cdot \mathbf{s}^{-1}$ & $\mathbf{N D T}-\mathbf{1 0 0 0} \mathbf{m m} \cdot \mathbf{s}^{-1}$ & NDT (mean) \\
\hline A & $1,400{ }^{\circ} \mathrm{C}$ & $1,410^{\circ} \mathrm{C}$ & $1,405^{\circ} \mathrm{C}$ \\
\hline B & $1,375^{\circ} \mathrm{C}$ & $1,365^{\circ} \mathrm{C}$ & $1,370^{\circ} \mathrm{C}$ \\
\hline
\end{tabular}

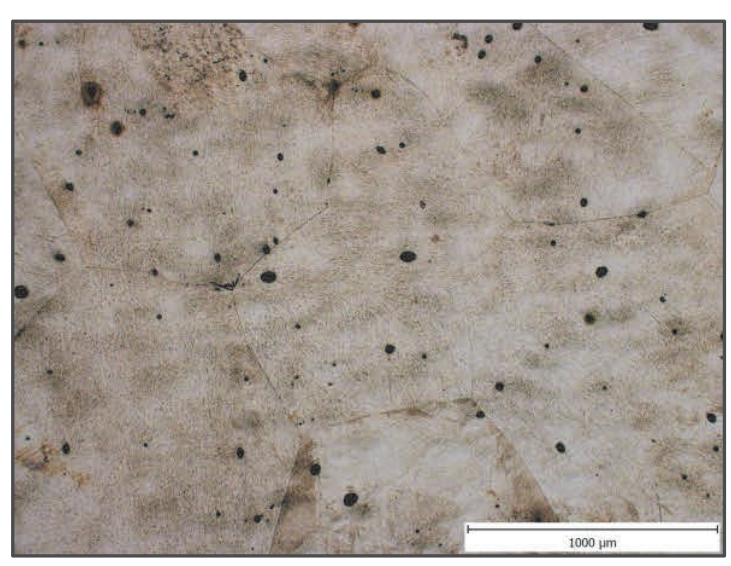

a) steel $\mathrm{A}$ - temperature of $1,400{ }^{\circ} \mathrm{C}$

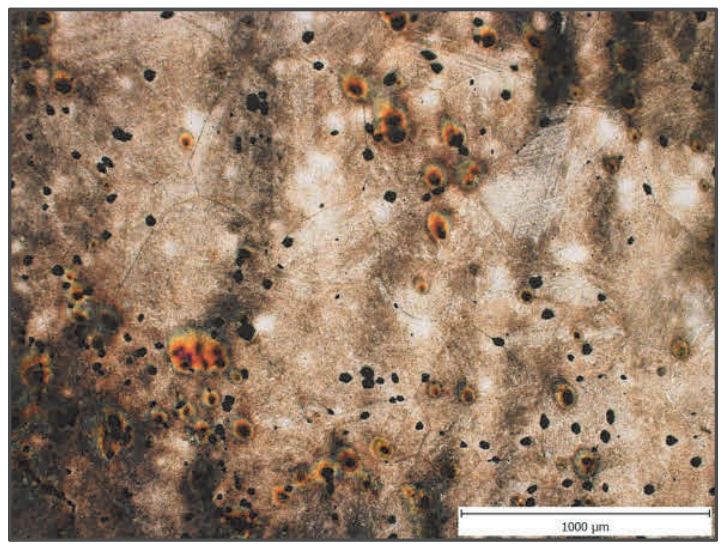

b) steel $\mathrm{B}$ - temperature of $1,350^{\circ} \mathrm{C}$

Figure 7 Example of photo documentation of initial austenitic grain after heating of investigated steels to selected temperatures

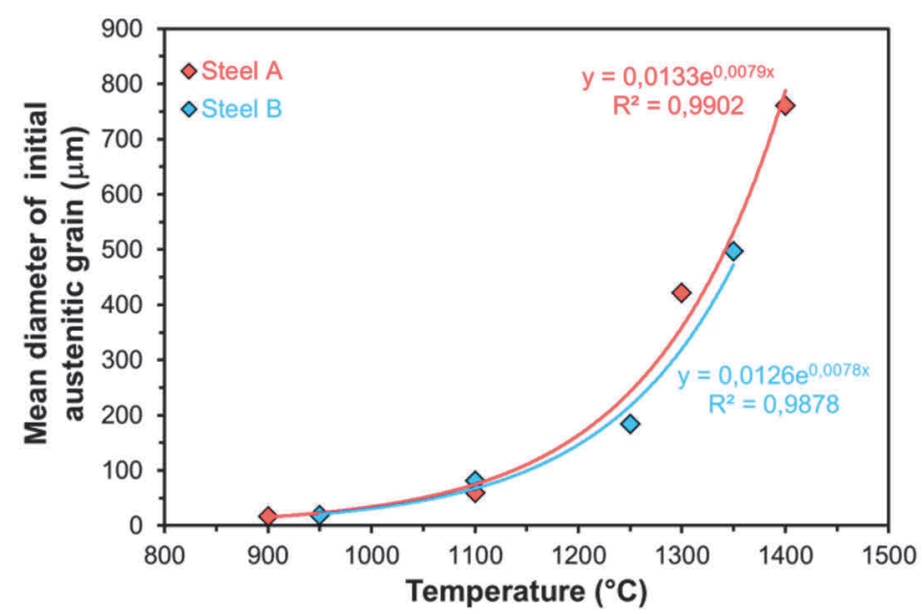

Figure 8 The mean diameter of the initial austenitic grain of the investigated steels 
Metallographic analysis was performed with the use of the traditional optical microscopy. It was determined that both investigated steels have significantly coarse austenitic grains at temperatures higher than $1,250^{\circ} \mathrm{C}$ (see Figure 7). In the case of temperatures $1,300^{\circ} \mathrm{C}$ and higher, this coarseness is accompanied presence of black forms inside and on the border of the austenitic grain, which most likely represent inclusions. Occurrence of inclusions at the border of the original austenitic grains causes brittleness at high temperatures. The mean diameter of the original austenitic grain $d_{\text {mean }}(\mu \mathrm{m})$ of the hot treated specimens was determined with using of a linear straight line method according to EN ISO 643 [16]. The mean diameter of the initial austenitic grain increased with rising temperature, and it is relatively simple to describe the exponential correlation for both investigated steels with simple equations - see Figure 8.

\section{CONCLUSIONS}

High heat strength and plastic properties of both selected low alloy Cr-Mo steels, differed in carbon and manganese content were investigated with the using of the simulator HDS-20.

The steel with higher content of carbon and manganese showed a $42{ }^{\circ} \mathrm{C}$ higher nil-strength temperature and a $35{ }^{\circ} \mathrm{C}$ higher nil-ductility temperature. It was confirmed, that the nil-strength temperature and nil-ductility temperature decreases with a higher content of carbon in steel, which corresponds to a decrease of solidus temperature in the metastability diagram $\mathrm{Fe}_{-} \mathrm{Fe}_{3} \mathrm{C}$. In addition, the influence of the heating temperature on the size of the austenitic grain was determined for both investigated steels and this dependence was described with great accuracy by exponential equations.

The achieved results can be used for the optimization of heating temperatures, for determining of upper forming temperatures, or for processes associated with welding of the both investigated steels.

\section{ACKNOWLEDGEMENTS}

The article was created thanks to the project No. CZ.02.1.01/0.0/0.0/17_049/0008399 from the EU and $C R$ financial funds provided by the Operational Programme Research, Development and Education, Call 02_17_049 Long-Term Intersectoral Cooperation for ITI, Managing Authority: Czech Republic Ministry of Education, Youth and Sports and within the students' grant projects SP2019/86 and SP2019/43 supported at the VŠB - TU Ostrava by the Ministry of Education, Youth and Sports of the Czech Republic.

\section{REFERENCES}

[1] RUSZ, S., SCHINDLER, I., HRBÁČEK, K., KAWULOK, P., KAWULOK, R. and OPĚLA, P. An investigation of the deformation behaviour of the nickel alloys IN 713 LC and MAR M-247. In: Metal 2015: 24th International Conference on Metallurgy and Materials. Ostrava: TANGER, 2015, pp. 403-408.

[2] VEDANI, M., RIPAMONTI, D., MANNUCCI, A. and DELLASEGA, D. Hot ductility of microalloyed steels. La Metallurgia Italiana. 2008. vol. 100, no. 5, pp. 19-24.

[3] LEE, CH. H., PARK J.-Y., CHUNG, J.H., PARK, D.-B., JANG, J.-Y., HUH, S., KIM, S. J., KANG, J.-Y. MOON, J. and LEE, T.-H. Hot ductility of medium carbon steel with vanadium. Materials Science and Engineering A. 2016, vol. 651, pp. 192-197.

[4] KAWULOK, P., KEMPNY, M., SCHINDLER, I., KAWULOK, R. and SOLOWSKI, Z. The influence of grain size on hot formability of steel C45. In: Metal 2017: 26th International Conference on Metallurgy and Materials. Ostrava: TANGER, 2017, pp. 364-369.

[5] SUN, Y.-H., ZENG, Y.-N. and CAI, K.-K. Hot Ductility of Ti-V Bearing Microalloyed Steel in Continuous Casting. Journal of Iron and Steel Research, International. 2014, vol. 21, no. 4, pp. 451-458. 
[6] MEJÍA, I., BEDOLLA-JACUINDE, A., MALDONADO, C. and CABRERA, J.M. Hot ductility behaviour of a low carbon advanced high strength steel (AHSS) microalloyed with boron. Materials Science and Engineering: $A$. 2011, vol. 528, no. 13-14, pp. 4468-4474.

[7] LI, J., JIANG, B., ZHANG, CH., ZHOU, L. and LIU, Y. Hot embrittlement and effect of grain size on hot ductility of martensitic heat-resistant steels. Materials Science and Engineering: A. 2016, vol. 677, pp. 274-280.

[8] GRAJCAR, A., ZALECKI, W., SKRZYPCZYK, P., KILARSKI, A., KOWALSKI, A. and KOLODZIEJ, S. Dilatometric study of phase transformations in advanced high-strength bainitic steel. Journal of Thermal Analysis and Calorimetry. 2014. vol. 118, no. 2, pp. 739-748.

[9] KUZSELLA, L., LUKÁCS, J. and SZÜCS, K. Nil-strength Temperature and Hot Tensile Tests on S960QL Highstrength Low-alloy Steel. Production Processes and Systems. 2013. vol. 6, no. 1, pp. 67-78.

[10] MANDZIEJ, S. T. Physical Simulation of Metallurgical Processes. Materials and Technology. 2010, vol. 44, no. 3, pp. 105-119.

[11] SAWICKI, S., DYJA, H., KAWALEK, A., KNAPIŃSKI, M., KWAPISZ, M. and LABER, L.B. High-temperature characteristics of $20 \mathrm{MnB} 4$ and 30MnB4 micro-addition cold upsetting steels and C45 and C70 high-carbon-steels. Metalurgija. 2016. vol. 55, no. 4, pp. 643-646.

[12] LUKÁCS, J., KUZSELLA, L., KONCSIK, Z., GÁSPÁR, M. and MEILINGER, Á. Role of the physical simulation for the estimation of the weldability of high strength steels and aluminum alloys. Materials Science Forum. 2015. vol. 812, pp. 149-154. ISSN 1662-9752.

[13] KOTÁSEK, O., RUSZ, S., SCHINDLER, I., KAWULOK, P. and OPĚLA, P. Plastic properties of steel AISI 4140 influenced by strain rate and temperature. In: Metal 2018: 27th International Conference on Metallurgy and Materials. Ostrava: TANGER, 2018, pp. 401-406.

[14] SONG, S.-H., JIANG, X. and CHEN, X.-M. Tin-induced hot ductility degradation and its suppression by phosphorus for a Cr-Mo low-alloy steel. Materials Science and Engineering: A. 2014, vol. 595, pp. 188-195.

[15] ZHENG, Y., WANG, F., LI, CH., CHENG, J. and LI, Y. Effect of compound addition of Nb-B on hot ductility of CrMo alloy steel. Materials Science and Engineering: A. 2018, vol. 715, pp. 194-204.

[16] European standard. EN ISO 643 Steels - Micrographic determination of the apparent grain size. Praha, 2013. $36 \mathrm{p}$. 